\title{
Analysis of the Corporate Social Responsibility (CSR) practices in Mexico and its relationship with the labor development and workers life quality
}

Profesor del Departamento de Administración, Centro Universitário de Ciências Económico-Administrativas, Universidad de Guadalajara. Zapopan [Jalisco] México <jvargas2006@gmail.com>.

\section{José Luis Soriano Sandoval}

Maestría en Negocios y Estudios Económicos. Universidad de Guadalajara. Zapopan [Jalisco] México $<$ lic.joseluisss@hotmail.com>.

\begin{abstract}
In recent years in Mexico, private and public institutions have implemented mechanisms to encourage companies to adopt practices focused on Corporate Social Responsibility (CSR), however, there has been a certain level of disbelief in society about the benefits generated Based on the practices of social responsibility implemented by the companies and especially on the quality of life of the collaborators, so that the analysis is performed, through a descriptive analytical method, that can better describe the phenomenon and detect if in reality The strategies implemented, on the practices of CSR in Mexico.
\end{abstract}

\section{Keywords}

Corporate culture. Diversity. Social responsibility. Business administration and business economics. Marketing. Accounting. Personnel economics. 


\section{Introduction}

This study aims to identify and analyze the application of corporate social responsibility practices and establish the relationship with labor development and the quality of life of workers, within their working environment, in Mexican territory. The above, is established based on the following lines of research: 1) Quality of life and sustainable development, 2) Sustainable social and local development, 3) Strategies, quality and sustainable development, and 4) Economics, strategy and sustainable development of organizations.

It identifies a complex problem regarding the effectiveness of social responsibility practices and their positive impact on the quality of life of workers. Various factors can be involved in the process, such as corruption, incompatible models, disinterest or simply by ignorance of the factors that generate a misinterpretation and / or application of corporate social responsibility. Although it is known, the verification of the effectiveness of these practices, as a marketing tool (Fernández, 2005).

Efficacy to improve the quality of life of workers is put to trial, although there are no indicators of development evaluation for workers working in companies that adopt social responsibility practices, one of the objectives of this work, is common to listen, the company bought the certification! Walmart is certified as ESR and pay very little! My company is said to be socially responsible and treat employees very badly! ¿What is happening? Various news in Mexico circulate, signaled to companies certified in SCR with acts of contamination, discrimination and corruption. Contrary to the practices established by the SCR, an example, is the news published by Excelsior in 2013 in the state of Jalisco, where a company certified with SCR practices, abused of labor abuse of workers, (Excelsior 2013).

In terms of the environment, it is not the meaning of the company Cloralex that implements SCR practices. The organization Womens Voice for earth has verified how some gases that contain chlorine, such as chlorofluorocarbons (CFCs) and HCFCs, destroy stratospheric ozone. It has also stated that the chloroform contained in Clorox can cause cancer (Womens Voices 2011). These questionings are not exclusive to Mexico. In the documentary The Hidden Side of Google can visualize the discontent of workers within a leading company in Social responsibility practices (Roland 2015).

Therefore, the purpose of the study is to serve the design of strategies for the improvement and / or solution of the development of the quality of life of workers with respect to companies that implement Social Responsibility Practices, since there is no Studies that analyze the impact on workers' quality of life, if not only the economic viability of the company (Öberseder 2011).

\section{Background}

The Corporate Social Responsibility (CSR) is understood as the active and voluntary contribution to social, economic and environmental improvement by companies, with the objective of improving their competitiveness, and its added value, according to the Ministry of Economy (SE 2016). For the International Labor Organization, the social responsibility of the company is the set of actions that companies take into account so that their activities have positive repercussions on society and affirm the principles and values by which they are governed, both in their own internal methods and processes as well as in their relationship with other actors (ILO, 2007, p.53).

The origin and evolution of the concept has six phases (Bhaduri, 2016):

- 1950-1960 : period of introduction of CSR in the academic field and corporate philanthropy as CSR;

- 1970s : period of rapid growth in the concept of CSR;

- 1980s : period of stakeholder theory and business ethics;

- CSR of the 1990s;

- 2000 onwards : empirical work period to investigate determinants and Consequences of CSR in corporate strategy.

(C) Labor \& Engenho, Campinas [SP] Brasil, v.11, n.4, p.530-538, out./dez. 2017. 
The concept of CSR has been studied from the economic, social and environmental point of view. Within an economic approach there are two main aspects of study, productivity in relation to the CSR model based on indicators of productivity in workers and the second is profitability as marketing techniques for consumers. This point is studied in depth and validated. In this approach the economic benefit is taken as the most important variable of study.

Social responsibility takes sustainability into consideration. Several authors agree, such as Haneke, Glosw, Hernand (1998) in a definition ad literam "development that satisfies the needs of the present generation without compromising the ability of future generations to meet their own needs".

Within the social perspective, studies are justified by productivity indicators tending to economic issues. However, there are no studies that verify the truthfulness of improving the quality of life of workers in relation to the establishment of CSR practices in the company that they work, which in turn, can influence the productivity of the workers and therefore in a decrease welfare in the society that ends in economic repercussions for the Mexican economic environment. From an environmental point of view, there are economic, environmental, and an example, the Kuznets environmental curve (Correa, Vasco, Pérez, 2015) that directly affect the company as a structure, the viability of legal framework in Mexico and its incentives towards the company, which also tends to be conditioned by economic factors.

As pollution vs. economic growth is a debate within the environmental sciences and economics. In addition to the above, the concept has also been studied from the biological point of view, which focuses on minimizing pollution regardless of economic costs or viability within the current economic system, tends to be more utopian (Gudynas 2009).

Sustainable development has become more a discourse than a resource, a way and a method of reconfiguring society and preserving nature and life itself (Salinas, 2007). The technical problem of this is to obtain an acceptable estimate of the social cost and externalities to bring the tax (or subsidy) in line, which raised the need to carry out, in collaboration with other specialists, environmental impact assessments that would serve as a basis for the desired pecuniary estimates. Even though the obligatory partiality and arbitrariness of such assessments has served most often to provide benign estimates of the social costs that justify state authorization of damages (Cruz, 2006).

Although the issue of CSR is not new, the line that investigates the impact of the application of CSR practices on workers has little depth of theoretical and methodological research, since research on the subject focuses more, the profitability of the company and its effectiveness as a marketing theme.

Certified models known in Mexico, Family Responsible Enterprise (EFR), Socially Responsible Enterprise (ESR), Including Company (DEI), the three above, are programs operated by the Federal Ministry of Labor and Social Prevention (STPS) (PROFEPA) and at the state level, exclusive of the state of Jalisco, the Voluntary Environmental Compliance Program (PCAV), in addition to ISO 26000 in Social Responsibility and ISO 14000 Focused on the environment, and lastly the A8000 certificate focused on the practices of corporate social development.

Do these certifications actually work? What do they work for? An example is the Family Responsible Company model, 5 years after its implementation, what benefits have been achieved? Does the quality of life of the workers actually increase?

An example more attached, is the Family Business model, which was replicated in Mexico through the program of distinctions awarded by the Secretary of Labor and Social Prevention (STPS). This program was developed by the business school of the University of Navarra, Spain, where through assumptions and theories of competitiveness and productivity in workers, justify the importance and feasibility of its implementation.

However, there are no studies that demonstrate the evaluation of the model, once it has been implemented. The most attached to this is the IESE FAMILY-RESPONSIBLE EMPLOYER INDEX developed by the same University of Navarra and analyzes the level of implementation of the Responsibility Familiar Corporate and its impact on people and organization. However, their studies 
do not take into account Mexico, so there is a lack of information regarding the feasibility of implementing these practices in Mexico and creates doubts, whether or not true these practices work as they say on their website.

The objectives of this analysis are to identify the variations that exist between the application of CSR practices within the company and the quality of life and development of workers. Hierarchize the importance of the most relevant factors within the application of the CSR. Provide information that serves to design strategies for the improvement and / or solution of the development of the quality of life of workers with respect to companies that implement Social Responsibility Practices. Establish links between CSR and the welfare of society.

\subsection{Justification}

The phenomenon of Social Responsibility is essential within the strategic planning of a company. however, in Mexico, this phenomenon is little studied and it is assumed that the implementation of social responsibility practices, will obtain positive results, but these results, few times are analyzed and evaluated. Therefore, some degree of disbelief in Mexican society is perceived on the benefits of these practices. In addition to the above, some news and the null results of the evaluations related to the CSR models to reinforce the hypothesis that the implementation of these models are not working for the companies, from the point of view, of the improvement in the quality of life of the workers.

\section{Theoretical-conceptual review}

The problem lies in the following way: To what extent do employees who work in companies with CSR practices improve their quality of life? Is there a relationship between the development and improvement of the quality of life of employees and the model of CSR? What factors intervene? Do SCR practices actually work to improve social welfare?

The political factor is an important variable, since it can influence directly or indirectly the way in which companies adopt the SCR practices. The theoretical limits of the problem are based on the assumptions in which companies adopting SCR practices have external certification issued by third parties, whether governmental or non-profit institutions.

The Geographic delimitation is Mexico, since it is where the problematic is identified and it is viable in questions of resources for the analysis. In addition, it can be a unit of comparison, with respect to the other countries, since they share characteristics (at country level) that can influence the study, such as culture, legal structure and applicable models.

The object of study and / or observation units, will focus on individuals working in certified companies and individuals who do not work in certified companies.

\subsection{Corporate Social Responsibility}

Social welfare is also a task for multinational corporations. The Ministry of Economy (SE 2017), through the National Contact Point, has the mission of promoting corporate social responsibility, through the Guidelines for Multinational Enterprises of the Organization for Economic Co-operation and Development (OECD). These guidelines are a set of principles and standards that seek to ensure that the operations of multinational enterprises: develop in harmony with public policies, strengthen trust between business and society, improve the climate for foreign investment, and increase the contribution of multinational companies to sustainable development. OECD member countries regularly review the guidelines to ensure that their content is updated and reflects global changes.

\subsection{Quality of life}

For the World Health Organization (WHO) quality of life complements the following factors, such as physical, psychological, facets of pain, energy, discomfort, sleep, rest, medications, mobility, reflection, feelings, work capacity, social support, opportunity to acquire financial loans, transportation, spirituality, 
among others less relevant. However, the main ones are those mentioned above and from which you can get to build indicators in order to evaluate their implementation and its efficiency (WHO, 2017).

\subsection{Well-being index}

For the Organization for Economic Cooperation and Development (OECD), welfare rates focus on improving people's well-being in order to achieve better policies for a better life. It is complex to talk about the concept of well-being since it is multidimensional and covers various aspects of life that has to do from housing, income, life-work quality and health-related competencies.

The most recent evidence on welfare is the 11 dimensions of life suggested by the OECD, which follows standards from the various points mentioned above related to the welfare issue, as was the initial hypothesis, the countries with the highest Gross Domestic Product (GDP), tend to have higher welfare indicators than those with lower GDP, which can be concluded that if there is a strong relationship between GDP and the welfare of each country, where the most relevant points are focus on pollution and employment (OECD, 2014).

\subsection{Social Responsibility Model}

Porter (2006) mentions the importance of the social responsibility model, and states that governments, activists and the media have become experts in holding corporations accountable for the social consequences of their actions. In response, corporate social responsibility has emerged as an inescapable priority for business leaders in all countries.

Since the efforts of corporate social responsibility are often counterproductive for two reasons independent of each other and secondly, companies are pressured to adopt social responsibility practices in a generic way without giving them an opportunity to adopt the practices in an organic way and more appropriate for their individual strategies. So the fact that CSR approaches are so disconnected from strategy is why many companies see this approach as an additional cost and yet as Whole Foods Market, Toyota and Volvo have done. Practices can be A powerful source of innovation and competitive advantage.

So Michael Porter (2006) proposes a fundamentally new way of looking at the relationship between business and society that does not address corporate growth and social welfare as a zero-sum game. They introduce a framework that individual companies can use to identify the social consequences of their actions. To discover opportunities that benefit society and themselves, strengthening the competitive context in which they operate. To determine which CSR initiatives to address; and to find the most effective ways to do it. Perceiving social responsibility as an opportunity rather than as a damage control or public relations campaign requires a radically different thinking - a mindset - the authors warn, which will become increasingly important to competitive success.

\subsection{Review of the empirical reading}

It was mentioned above that, within the social perspective, studies are justified by productivity indicators (tending to economic issues). However, there are no studies that prove the truthfulness of improving the quality of life of workers in relation to the establishment of practices of CSR in the company that work, which in turn, can influence the productivity of the workers and therefore in a decrease welfare in the society that ends in economic repercussions for the Mexican economic environment.

Although the issue of CSR is not new, the line that investigates the impact of the application of CSR practices on workers has little depth of theoretical and methodological research, since research on the subject focuses more, the profitability of the company and its effectiveness as a marketing theme.

In Mexico there is very little information on the subject of social responsibility, but it is possible to identify the null documents referring to the evaluation of established practices of CSR. 


\section{Conceptual framework}

The concept of well-being is very complex since each individual has a different perception of reality and therefore, the definition established by the OECD, for that institution, welfare is taken up, is considered as the priority of an individual to be happy, so that to elaborate the welfare index, 11 indicators were developed, which are: Housing, expenditures, employment, community, education, environment, civic commitment health, satisfaction, safety, work life balance. The latter is the most important for the study, since the hypothesis focuses on the fact that the balance of life.

Work does not improve, with the "Social Responsibility Practices" of a company certified in this model. As a result of the study, the OECD (2017) defines it as finding the right balance between work and the daily life of each person, without but it is a challenge faced by all workers. In general, families are the most affected, since the ability to successfully combine work, personal commitments and family life is important for the whole family. In this respect, governments can support facilitating means of well-regulated legal frameworks that can support workers in this regard.

Based on the above, the questionnaire was developed and later complementary aspects such as those defined below (OECD 2017) are taken into account since the time devoted to leisure and personal care, in addition, the more people work, the less time they will have to dedicate it to other activities, such as personal care or leisure. The quantity and quality of free time are important for the general well-being of people and can generate additional benefits for physical and mental health. A full time employee at the OECD devotes on average $62 \%$ of the day, about 15 hours, to personal care (eating, sleeping, etc.) and to leisure (social life with friends and family, hobbies, games, computer and television, etc.). A shorter work schedule for women does not necessarily equate to more leisure time, since leisure time is approximately the same for men and women in the 20 OECD countries studied.

On the other hand are the definitions by the Business School of the University of Navarra, which refers to the following:
a) Promote Corporate Family Responsibility that facilitates satisfaction and results.
b) To promote the flexible and responsible leadership that favors the commitment and the family and labor enrichment.
c) Promote the adoption of flexible policies that enhance motivation and customer orientation.
d) Provide the tools and diagnostics needed to create flexible and enriching environments (Escuela de Negocios Universidad de Navarra, 2017).

In addition to the above, the following points are added (Business School University of Navarra 2017). The factors that affect productivity are multiple and are related to each other. Among the variables that facilitate productivity, IFREI focuses on two key factors: people commitment and motivation, and management policies and strategy. Rotation and lack of commitment have negative consequences that affect the company's results:
a) Lower productivity.
b) Loss of experience.
c) Greater rotation.
d) Deterioration of the environment and the working environment.
e) Non-perception of the emotional salary.
f) Lack of commitment to the company.
g) Increased stress and associated diseases.
h) Smaller creativity and initiative.
i) Difficulty attracting and retaining talent.

There are also other significant direct costs:

a) Absenteeism.

b) Cost of selection for replacement. 
c) Cost of training a new employee.

d) Cost of replacing the replacement time.

All of the above takes the view that there is a suspicion that social responsibility practices in Mexico do not improve the quality of life of workers and their professional development, perhaps because of their poor implementation, because they grant the certificates to companies, without a true verification of the practices or simply because the CSR model, does not work to improve the quality of life of workers.

\section{Research Methods}

A quantitative and qualitative analysis is used, through surveys applied to workers working in a company in Jalisco, with certified practices of social responsibility, where the answers are used to analyze previously created indicators, to identify the relationship between variables and the factors that can intervene.

The questions are taken from the OECD welfare indexes, specifically from the Work Life Balance Indicator, since the model of the University of Business of Navarra, Family Responsible Employer Index IFREI, model that is taken up by the STPS in Mexico and that ensures its positive impact on this indicator, so it is decided to return to this indicator as a basis for the questions. The questionnaire is applied to workers who work in companies with certificates of "Socially Responsible and Family Responsible Company", since they are the certificates that return to these CSR models.

Therefore, the following questions were used:

a) Do you have knowledge that your company has certification in Social Responsibility? $\mathrm{R}=$ yes $/$ no

b) How many hours do you work a week?

c) What kind of benefits do you get compared to another company, if you get them?

d) Do you think that you are satisfied with the Company's Social Responsibility practices? $\mathrm{R}=$ Very Satisfied, Satisfied, Satisfied, Satisfied.

e) Do you think the company deserves the certificate?

f) In addition to the previous questions, the age and sex of the interviewed worker were registered, so that the questionnaire was presented to the interviewees.

g) Any additional comments, complaints or suggestions?

h) $\mathrm{R}=$ Yes / No

The questionnaire was applied to 50 people employed in a company located in the state of Jalisco with certificates of Corporate Social Responsibility anonymously.

\section{Results}

The most relevant results showed that workers are not satisfied with the social responsibility practices applied by the company, in addition to the fact that most do not know the policies of the company as a whole and did not have the knowledge that the company was with a current certification in Corporate Social Responsibility.

This is of the utmost importance, since it demonstrates a failure in the implementation of the Social Responsibility actions, since one of the objectives is to make known to the internal members of the company and in general to the stakeholders, the activities that are implemented within the company. It is identified that only the area of human resources, generally, who is who operates the policies, are the only ones that know in full the activities that the company employs.

Continuing with the results, it can be observed that the respondents have a certain level of disagreement with the way in which the certificate is granted to the companies, since the majority disagrees with the award of the certificate to the company for the practices, and who mention that the company has never 
implemented some Social Responsibility practices that are indispensable for the granting of the certificate, even $27 \%$ of the respondents mention that the company works outside the law, which would automatically turn the company into a null candidate to acquire or even participate in certificate programs, related to social responsibility.

Specifically, the hours of work, in the majority of interviewees, show that companies are within the limit of allowed hours of work, so that although companies carry out CSR activities, the workload is not taken into account. Account in most cases, this limits the positive impact on the quality of life of workers.

In terms of gender equity, the results presented remarkable benefits, since the respondents say that the treatments for men and women are the same within the CSR policies detected in the company.

\subsection{Conclusions and recommendations}

It can be concluded that the practices of social responsibility within the company are not well founded in Mexico, since the CSR models are not adapted to be applied satisfactorily in the companies located in Mexico, since they try to apply exactly as in other countries with dubious benefits, so it is necessary to make adjustments and adapt it to the Mexican environment, always respecting its laws and regulations in labor matters.

With respect to the impact of workers' quality of life, a positive impact is identified as it ensures that most employees do not obtain relevant benefits that increase their quality of life, apparently the institutions that are dedicated to certifying such practices in Mexico, fail to apply their audit tools efficiently, as it leaves much doubt as to how they award the certifications to the companies participating in the programs.

In this sense, the most essential aspect of CSR should be the main focus, to raise the quality of life of workers, leaving aside the current priorities, such as marketing benefits and environmental care, which only increase the discourse of companies, but it is not taken seriously the common benefit of all individuals, since the pursuit of common benefit, is the true objective of corporate social responsibility policies.

In order to reinforce policies, it is necessary to follow the policies implemented by the company and to carry out an evaluation analysis every year, in order to detect possible improvements, errors and tangible direct benefits to improve the quality of life of workers.

In Mexico, CSRs have had very little evaluation, which limits credibility and creates uncertainty in society, so it is important for current projects to implement their evaluation.

\section{References}

Bhaduri, L. (2016) La importancia de la responsabilidad social empresarial, evolución del concepto. Negocios y entorno, 32(4), 7-17.

Correa, F., Vasco, A., \& Pérez, C. (2005) La curva medioambiental de Kuznets: evidencia empírica para Colombia. Semestre económico 8(15), 13-30.

Escuela de Negocios Universidad de Navarra (2017). Beneficios de implementar IFREI. Empresa y negocios, $2(7), 16-32$.

Cruz, C. (2006), Valoración de bienes y recursos ambientales y naturales: el problema de la medición. Registro Colombia, 21(2), 11-17.

Excelsior (2013). Empresas que abusan de jornaleros eran "Socialmente Responsables". México: recuperado de http://www.excelsior.com.mx/nacional/2013/06/13/903900\#view-1. 
Fernández, D. (2005). ¿Existe disponibilidad a pagar por responsabilidad social corporativa? Percepción de los consumidores. Universia Bussiness Review, 7(3), 38-53.

Gudynas, E. (2009). La ecología política de la crisis global y los límites del capitalismo benévolo. Iconos de Ciencias Sociales, 6(36), 53-67.

Haneke, D., Glosw R., \& Hernand S. (1998). Medio Ambiente y desarrollo sustentable. Revista sustentable LDC, $3(2), 18-24$.

Öberseder, M. (2011). Why Don't Consumers Care About CSR? A Qualitative Study Exploring the Role of CSR in Consump-tion Decisions. Journal of Business Ethics, 104(4), 449-460.

OCDE (2017). Índice de Felicidad. New York [EUA]. Recuperado de: http://www.oecdbetterlifeindex.org/ es/topics/work-life-balance-es/.

OCDE (2014). How's Life? 2015: Measuring Well-being. OCDE Publishing. doi: 10.1787, how_life-2015-en Organización International del Trabajo 2007.

OIT (2007). Organización Internacional del Trabajo, ¿Quiénes somos?. Informe, P.53. Recuperado de http:// www.ilo.org/inform/online-information-resources/research-guides/lang--es/index.htm

OMS (2017) Referencia y definiciones. [EUA]. Recuperado de http://www.who.int/es/

Porter, M. (2006). Strategy and Society: The Link Between Competi-tive Advantage and Corporate Social Responsibility. Harvard Business Review, 84(12), 78-93.

Roland, S. (2015). The Hidden Side of Google. Francia, 68min.

Salinas C. (2007). El desarrollo Sustentable. En: Memorias del Segundo Congreso de Investigación sobre Sustentabilidad y Calidad de Vida, UAEM, 2(2), 12-21.

SE (2017). Definición de Responsabilidad Social Empresarial. México. Recuperado de https://www.gob.mx/ se/articulos/responsabilidad-social-empresarial-32705

SE (2017). Punto nacional de contacto. México. Recuperado de https://www.gob.mx/se/articulos/ responsabilidad-social-empresarial-32705

Womens Voices (2011) Los hechos sucios de las compañías con certificados de sociablemente responsable. México. Recuperado de http://www.womensvoices.org/wp-content/uploads/2011/12/Dirty-Secrets-FactSheet-spanish.pdf. 